\title{
PTGFRN wt Allele
}

National Cancer Institute

\section{Source}

National Cancer Institute. PT GFRN wt Allele. NCI Thesaurus. Code C102812.

Human PT GFRN wild-type allele is located in the vicinity of 1p13.1 and is approximately 80 $\mathrm{kb}$ in length. This allele, which encodes prostaglandin F2 receptor negative regulator protein, plays a role in inhibition of ligand-receptor interactions. 